\title{
TOWARD ELIMINATING GENDER BIAS IN PERSONAL INJURY AWARDS: CONTRIBUTIONS FROM FAMILY ECONOMICS
}

\author{
JANET E. FAST and BRENDA MUNRO•
}

The legal system has been slow to recognize the value inherent in housework. This has resulted in gender bias in compensating victims of personal injuries for their reduced ability to perform household work. Although there has been significant progress in the legal system, several sources of undercompensation remain. The authors support the suggestion that significant progress can be achieved by reconceptualizing the loss as that of the capacity to do economically valuable work. Calculation of lost housekeeping capacity remains problematic as the courts tend to underestimate the amount of time individuals spend performing unpaid work. Further controversy involves the appropriate method for estimating the value of non-market work. Replacement cost methods are recommended. Such an approach will not eliminate gender bias as it merely reflects the gender bias in the market.
Le système judiciaire aura mis du temps à reconnaitre la valeur inhérente des travaux ménagers. Cette lenteur a engendré un certain parti pris contre l'autre sexe dans la compensation des victimes de préjudices corporels qui ont perdu la capacité d'effectuer les travaux ménagers. Bien qu'on note un progrès sensible à ce sujet, plusieurs sources de sous-compensation subsistent. Selon les auteurs, il serait possible de marquer des progrès importants en repensant la perte comme impliquant la capacité d'effectuer un travail d'une certaine valeur économique. Le calcul des pertes résultant de la capacité amoindrie d'effectuer des travaux ménagers reste problématique, car les tribunaux tendent à sous-estimer le temps consacré au travail non payé. La controverse se poursuit quand il s'agit d'adopter une méthode appropriée qui permettrait d'évaluer la valeur des activités non rémunérées. Les auteurs recommandent l'adoption de méthodes d'évaluation au coût de remplacement. Mais une telle approche n'éliminera pas les partis pris, qui reflètent simplement les attitudes prévalant sur le marché.

\section{TABLE OF CONTENTS}

I. INTRODUCTION AND PURPOSE $\ldots \ldots \ldots \ldots \ldots \ldots \ldots \ldots$

II. THE HISTORICAL CONTEXT OF CLAIMS FOR LOST HOUSEKEEPING CAPACITY $\ldots \ldots \ldots \ldots \ldots \ldots \ldots$

III. SOURCES OF UNDERCOMPENSATION FOR DIMINISHED HOUSEKEEPING CAPACITY $\ldots \ldots \ldots \ldots \ldots 4$

A. FAILURE TO MAKE THE CLAIM $\ldots \ldots \ldots \ldots \ldots \ldots$

B. WHAT HEAD OF DAMAGE? ............. 5

C. WHAT IS THE CAPACITY LOST AND HOW

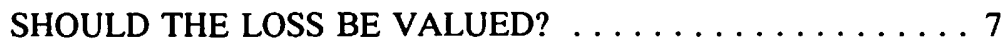

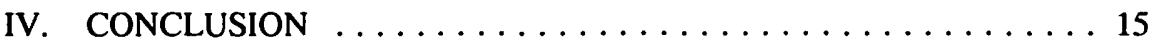

\section{INTRODUCTION AND PURPOSE}

In 1985 the United Nations General Assembly adopted a resolution calling for recognition of women's contributions to development in the form of unpaid labour in agriculture, food production, reproduction and household activities. ${ }^{1}$ The resolution also

Department of Human Ecology, University of Alberta.

1 Effective Mobilization and Integration of Women in Development, GA Res. 40/204. 
calls for the value of these contributions to be measured and reflected in economic statistics such as Gross National Product (GNP). A bill known as the Unremunerated Work Act was introduced in the U.S. Congress. ${ }^{2}$ If passed, the bill would require the Bureau of Labour Statistics to conduct studies of unwaged labour of men and women, to calculate the monetary value of this labour and to include that value in calculations of the nation's GNP.

In contrast, the Canadian legal system has been slow to recognize the economic value of unpaid work such as the household work of family members. For example, in 1983 Agrios J. awarded only $\$ 1,500$ per year for loss of housekeeping services to a plaintiff whose wife had been killed in a hunting accident, even though the deceased wife had performed most of the household work. ${ }^{3}$ Even as recently as 1992, the plaintiff in Logozar v. Golder was awarded a total of $\$ 6,552.00$ for pre-trial loss of voluntary services despite evidence indicating that Mrs. Logozar's housekeeping capacity had been reduced by more than 1,300 hours per year for nearly five years between her injury and the trial. ${ }^{4}$

Household work done by family members often is described as "invisible" since it is done largely by women, within private households, without pay and without social recognition. ${ }^{5}$ In developed economies there is a tendency to equate value with money. Consequently unpaid household work often is viewed as being valueless and therefore not even real work. As André states, "the homemaker's problems begin with the deceptively simple fact that she receives no salary for her work".

Many social injustices arise from the invisibility of unpaid household work. One such injustice, alluded to in the above examples, is persistent gender bias in compensating victims of personal injuries for their diminished capacity to perform productive but unpaid household work. This gender bias can be attributed to many causes. Claims for lost housekeeping capacity are rare. When they are made, it often is difficult for plaintiffs to convince the courts that the inability to do household work represents a compensable loss. Even in cases in which the courts have been willing to accept that diminished housekeeping capacity has resulted from injury and that this diminished capacity represents a compensable loss, awards typically undercompensate victims. This

H.R. 966, 103rd Cong., 1st Sess. (1993).

McNichol v. Mardell, [1983] 3 W.W.R. 299 (Alta. Q.B.), rev'd on other grounds [1984] 5 W.W.R. 177 (C.A.). Leave to the S.C.C. refused 58 A.R. 38n.

7 Alta L.R. (3d) 44 (Alta Q. B.) [hereinafter Logozar]. The award was based on the judge's finding that the plaintiff's housekeeping capacity had been reduced by 18 hours per week, rather than the 25 hours per week claimed and for a period of one year rather than the almost five years claimed. Further, the lost housekeeping capacity was compensated at a rate of $\$ 7.00$ per hour rather than the market replacement rate of $\$ 8.48$ per hour submitted by the expert family economist who testified at trial.

s See M. Eichler, Families in Canada Today, 2d ed. (Toronto: Gage Educational Publishing Company, 1988). See also S.J. Wilson, Women, the Family and the Economy (Toronto: McGraw-Hill Ryerson, 1986).

6 R. André, Homemakers: The Forgotten Workers (Chicago: University of Chicago Press, 1981) at 12. 
undercompensation often is excused by a perceived inability to properly value unpaid work.

The primary purpose of this paper, therefore, is to examine the extent to which undercompensation in personal injury awards can be demonstrated to arise from a failure to properly conceptualize and/or value loss of housekeeping capacity. The historical context of awards for diminished housekeeping capacity is briefly reviewed and sources of bias depressing awards for diminished housekeeping capacity in current case law are examined. Methodologies used and estimates generated by family economists are reviewed and their contribution to eliminating at least some of the sources of bias is discussed.

\section{THE HISTORICAL CONTEXT OF CLAIMS FOR LOST HOUSEKEEPING CAPACITY}

The legal system, like society in general, has long devalued unpaid work carried out in the household. Until fairly recently, damages for the loss of ability to do unpaid work seldom have been considered by the courts. In Canada, the first recognition that unpaid household work has value and that the value is pecuniary (economic), came in 1885 from Ritchie C.J., in St. Lawrence \& Ottawa Rwy v. Lett who stated that "the loss of a mother may involve many things which may be regarded as of a pecuniary character". ${ }^{7}$ However, even at a time in legal history when courts were willing to entertain claims for such damages, women could not recover damages because they lacked the property rights which would allow them to sue in their own names. Since a woman's husband was assumed to own and be the main beneficiary of her household work, he could sue for loss of his wife's services and any award would accrue to him. Even with the advent of property rights for women and the power to sue in their own right, husbands' claims for lost household services continued. St. Lawrence also established the principle in Canada that a husband was entitled to claim for the loss of his wife's services. ${ }^{8}$ The statement, "there is no doubt that an economic loss has been experienced by those survivors who were dependent on the housewife's services"9 seems to reflect the prevailing view of the time. A husband's right to recover for loss of a wife's services was even legislated in some jurisdictions. ${ }^{10}$

It is now more widely recognized, however, that the loss of the capacity to do unpaid work is personal to the injured individual. In Canada the demise of husbands' claims for loss of wife's services began with the recent landmark decision by Vancise J.A. in Fobel v. Dean ${ }^{11}$ where he concluded that the practice of compensating the husband for loss of services rendered by the plaintiff is "antiquated if not sexist: see Fleming, The Law of Torts (5th ed. (1977) p. 218, fn. 16)." Referring to the decision of the English Court of

(1885), 11 S.C.R. 422 at 426 [hereinafter St. Lawrence].

Ibid. at 422-23.

S.M. Speiser, Recovery for Wrongful Death: Economic Handbook (Rochester, N.Y.: Lawyers' Co-operative Publishing Company, 1970) at 196 [emphasis added].

See for example, P. Webb, "The Family Law Reform Act, 1978" (1977-78) I Advocate's Q. 367.

(1991), 83 D.L.R. (4th) 385 at 395, [1991] 6 W.W.R. 408 at $422-23$ (Sask. C.A.) [hereinafter Fobel, cited to D.L.R.]. Leave to the S.C.C. refused March 2, 1992, 2 W.W.R. xxii. 
Appeal in Daly v. General Steam Navigation Ltd. ${ }^{12}$ Vancise J.A. concluded that "a victim was entitled to be compensated in her own right for the loss she suffered." ${ }^{13} \mathrm{He}$ went on to cite the appeal judge in Daly who adopted the trial judge's statement that an injured homemaker "is just as much disabled from doing her unpaid job as an employed person is disabled from doing his paid one. ${ }^{14}$

The above represents significant progress in the way in which the Canadian legal system deals with the matter of unpaid household work of family members. Yet progress has been slow and many sources of discrimination remain. Claims for lost housekeeping capacity are still relatively infrequent and, as Cooper-Stephenson and Saunders ${ }^{15}$ and Eidsvik $^{16}$ observe, the amounts awarded have been highly variable but generally low.

\section{SOURCES OF UNDERCOMPENSATION FOR DIMINISHED HOUSEKEEPING CAPACITY}

The problem of determining appropriate compensation for those suffering personal injuries that affect housekeeping capacity has been addressed at length in the legal literature and in case law. The primary sources of undercompensation that can be identified include: underrepresentation of claims for lost housekeeping capacity; assignment of the loss to the wrong head of damage; lack of awareness of the magnitude of family members' contributions to family well-being in the form of unpaid household work; and lack of awareness of and agreement about appropriate techniques for valuing lost housekeeping capacity.

\section{A. FAILURE TO MAKE THE CLAIM}

It is still the case that claims for lost housekeeping capacity are underrepresented in the case law. For example, Harris et al. present evidence that, in England, women represent $43 \%$ of the accident victims but only $30 \%$ of all claims for damages. ${ }^{17}$ Homemakers alone represent $14 \%$ of all accident victims but only $5 \%$ of all successful plaintiffs. ${ }^{18}$ Cassels concluded that even when claims for damages arising from personal injury are filed by women, few include claims for lost housekeeping capacity. ${ }^{19}$

Claims for lost housekeeping capacity are even less likely to be filed by men. In fact, the widespread assumption that housework is "women's work" is probably the major

[1981] 1 W.L.R. 120, [1980] All E.R. 696, aff'g [1979] 257 [hereinafter Daly cited to W.L.R.]. Supra note 11 at 395.

Fobel, supra note 11 at 395 citing Daly at 126.

K.D. Cooper-Stephenson \& I.B. Saunders, Personal Injury Damages in Canada (Toronto: Carswell, 1981) at 214.

K.M. Eidsvik, "The Value of Housekeeping Services" (Paper presented at the Mid-Winter Meetings of the Alberta Bar Association, Edmonton, 1992) [unpublished].

D. Harris et al., Compensation and Support for Illness and Injury (Oxford: Clarendon Press, 1984) at 51 .

Ibid. at 56.

J. Cassels, "Damages for Lost Earning Capacity: Women and Children Last!" (1992) 71 Can. Bar Rev. 445 at 479. 
source of gender bias in personal injury claims for men. Note, for example, the assumption of gender-based division of labour expressed by the earlier quote from Daly that an injured homemaker "is just as much disabled from doing her unpaid job as an employed person is disabled from doing his paid one. ${ }^{\text {"20 }}$ The extent to which claims for diminished housekeeping capacity have been made by male plaintiffs is not known. However, it appears that few such cases have gone to trial in Canada. In rare instances, awards have been made to men (and even more rarely to women) for their inability to carry out the "manly chores" such as yard work and home maintenance. ${ }^{21}$ The single known exception is Hunter v. Manning in which Gunn J. awarded damages specifically for lost housekeeping capacity because the plaintiff, a 49 year old divorced man with no dependents, had "been restricted in his ability to attend to normal housekeeping and house maintenance duties since the accident. ${ }^{222}$

\section{B. WHAT HEAD OF DAMAGE?}

Another source of undercompensation is found in the debate revolving around the question of under what head of damage losses associated with reduced ability to perform unpaid work properly belongs. As Réaume points out, in cases in which awards for lost housekeeping capacity are made, "the grounds upon which the damages are awarded are confused." ${ }^{123}$ In some cases, losses associated with reduced housekeeping ability have been compensated as non-pecuniary damages (that is, damages for loss of enjoyment of life or loss of the amenities of life) ${ }^{24}$ However, as Cassels points out, limits on this head of damage will surely result in undercompensation in many cases, especially those involving serious, lifelong disabilities. ${ }^{25}$ Further, even ignoring the possibility that one may not actually enjoy (at least some aspects of) household tasks, characterizing the loss of housekeeping capacity as the loss of enjoyment of life rejects the notion of household activities as productive work.

In other cases, pecuniary damages have been awarded for lost housekeeping services/capacity, but there is little agreement as to how those damages should be characterized. The main issue debated is whether damages should be assessed as loss of earnings or loss of earning capacity. This debate can be summarized as follows. If loss of earnings is the basis for assessment, the plaintiff is compensated for earnings $\mathrm{s} / \mathrm{he}$ no longer receives because of the injury and no award will be made for loss of the capacity to do work that was not, and was unlikely in the future to be, paid work. Consequently, no award would be made for loss of the ability to do unpaid household work. If lost earning capacity is the basis for assessment, plaintiffs are compensated for earnings they might have received if their human capital had been used in paid employment whether it actually was or not. A homemaker could be compensated for what s/he could have earned

Supra note 12 at 126 [emphasis added].

D. Réaume, "Rethinking Personal Injury Damages: Compensation for Lost Capacities" (1988) 67 Can.

Bar Rev. 82 at 93 . See also Fobel, supra note 11 at 466 note 76.

(1993), 108 Sask R. 26 (Q. B.) at 38.

Supra note 21 at 89.

Cassels, supra note 19 at 477 note 29. See also Réaume, supra note 21 at 89.

Cassels, ibid. at 478. 
in the labour market. Neither of these approaches satisfactorily deals with the issue of lost housekeeping capacity. The first clearly ignores the intrinsic value of the household work itself. The second ignores the intrinsic value of the capacity to do household work and that such capacity is conceptually distinct from earning capacity.

In a few cases, awards for lost housekeeping services/lost housekeeping capacity have been made under a separate head of damages for homemakers. For example, in Urbanski v. Patel $^{26}$ the plaintiff was awarded damages pertaining to loss of her ability to care for a garden and animals that provided food for her family. In Rietze v. Bruser (No. 2) the plaintiff's "loss of function of the left hand which curtailed and, in some cases, prevented her performing such simple household tasks as sewing, knitting, washing dishes, etc." was cited as an important consideration in the judge's award of $\$ 15,000 .{ }^{27}$

However, several problems remain. Most of the discussion regarding how to characterize the pecuniary losses associated with diminished housekeeping capacity invites the conclusion that, for those employed in the labour market full time, damages should be awarded for lost earnings/earning capacity. ${ }^{28}$ Where the individual is a full time homemaker, however, damages should be awarded for lost housekeeping services/capacity, usually measured as the replacement cost of the services. There are several disturbing consequences of this practice. First, since the basis for compensation is labour market earnings (actual or potential), it continues to reinforce the notion that household work is not "real" work. Second, it precludes awarding damages for lost housekeeping capacity to those who are employed full time throughout the year. Yet data shows that, while employed women spend fewer hours doing household work than do full time homemakers, most employed women retain primary responsibility for and spend many hours doing household work. ${ }^{29}$ Consequently, limiting their claim to loss of earnings/earning capacity is likely to result in undercompensation. The practice also would result in undercompensation for employed men as it ignores their contributions in the form of unpaid household work just as it ignores the contributions of employed women. The legal literature and case law abound with implied assumptions that women are solely responsible for household work. While data confirm that women retain the major responsibility for household work, many men do participate in household production and their contributions should not be ignored. ${ }^{30}$

(1978), 84 D.L.R. (3d) 650 (Man. Q.B.).

[1979] 1 W.W.R. 31 at 54 (Man. Q.B.).

In such cases the practical result is about the same since earning capacity is generally measured as what the plaintiff was actually earning at the time of injury.

See especially Statistics Canada, Housing, Family and Social Statistics Division, Where Does Time $G o$ ? by A.S. Harvey, K. Marshall \& J.A. Frederick, (Ottawa: Statistics Canada, 1991) at 54, 57 and 61. See also J.P. Robinson, How Americans Use Their Time: A Socio-Psychological Analysis of Everyday Behavior (New York: Praeger Publishers, 1977). See also K.E. Walker, "Time Measurement and the Value of Non-Market Household Production" in C. Hefferan, ed., The Household as Producer: A Look Beyond the Market (Washington, D.C.: American Home Economics Association, 1980) 119.

Ibid. 
Réaume, building on a proposal by Cooper-Stephenson and Saunders, ${ }^{31}$ makes a convincing case for reconceptualization of the loss of earnings/earning capacity head of damages and presents a practical, conceptually appealing characterization of the plaintiff's loss as that of the capacity to do economically valuable work. ${ }^{32}$ She argues that for a loss to be considered pecuniary it need not be tied to earnings. Rather, all that is required is that it be capable of assessment in monetary terms. Since at least some aspects of household work are readily assessed in monetary terms, lost housekeeping capacity clearly is placed in the category of a pecuniary loss. Compensating on the basis of the use to which the individual actually put their human capital also comes closer to achieving the goal of returning plaintiffs to their pre-injury situation. Réaume suggests a two-stage process: determining what the plaintiff used to do that s/he can no longer do and calculating the value of those activities for which a monetary value can be determined.

In sum, Réaume's reconceptualization solves the problem of how to characterize the loss of housekeeping capacity - the loss is that of the ability to do productive work, the monetary value of which can be assessed, and so is economic. Yet the problems of how to determine the extent of the loss of capacity to perform household work and of how to calculate the value of the lost capacity remain, problems which also result in undercompensation of victims of personal injury. Since Réaume's concept of loss of the capacity to work is entirely consistent with household production economics, at least partial solutions to these problems can be found in the family economics literature.

\section{WHAT IS THE CAPACITY LOST AND HOW SHOULD THE LOSS BE VALUED?}

While Canadian courts have shown themselves to be increasingly willing to accept that lost housekeeping capacity is, in principle, compensable and have largely outgrown the belief that it is impossible to calculate a value for the loss of a capacity that is not traded on the market, there is little agreement as to how best to estimate the value of that lost capacity. Calculating the precise value of household work done by family members has always been problematic. However, recent efforts by researchers have given rise to several techniques for estimating the value of non-market work. Since "the main link between the household and economy is the value of human time" ${ }^{33}$ most of these techniques rely upon the valuation of time spent performing non-market work. Consequently two issues must be resolved. The first is how much time the individual spends performing unpaid work. The second is what "price" should be applied to that time.

\section{Lost Capacity}

Even when courts are willing to entertain claims for damages for lost housekeeping capacity and to characterize them as economic losses, awards have tended to be low for a variety of reasons, including a tendency to underestimate the amount of household work 
done by family members. Typical are assertions such as that of Wilson J. who, in Logozar, stated "I am also of the view that the hours claimed are excessive for a two person household. ${ }^{134}$ In Mayes v. Ferguson and Stettner ${ }^{35}$ the judge assumed that housekeeping capacity would decline with age such that the family would probably have hired a housekeeper in the future anyway. Yet there is abundant evidence that contradicts such conservative estimates of family members' contributions of household labour.

Time allocation studies in North America date back to the early 1900s. During the 1920s and 1930s a series of time use studies was sponsored by the Bureau of Home Economics of the U.S. Department of Agriculture. ${ }^{36}$ This early research helped to identify and classify diverse household tasks and to identify family and other characteristics that are related to the amount of time family members devote to household work. However, many of these studies were limited to farm women ${ }^{37}$ in selected geographic areas. The 1965 Robinson-Converse study was the first to use a national sample of women and men. ${ }^{38}$ More recent national time use surveys include the "Time Use Longitudinal Panel Study, 1975-1981" collected by the Survey Research Centre, at the University of Michigan and the 1985 "Americans Use of Time Project" conducted at the University of Maryland.

In Canada time use studies have been rare. The first was conducted in Halifax in 1965 while the first national time use survey was piloted in 1981 . Since then national surveys of time use have been included in the 1986 and 1992 waves of Statistics Canada's General Social Survey.

These time allocation studies have invariably demonstrated that a significant amount of unpaid productive activity is carried out within the household. They also invariably demonstrate that the vast majority of this household production is carried out by women. Table 1 shows estimated weekly hours devoted to household work and primary child care $^{39}$ by Canadian men and women as revealed by Canadian time use studies. Employed women are shown to spend, on average, between 18.9 and 29.4 hours per week doing household work while full time homemaker women average between 35.4 and 66.6 hours per week. ${ }^{40}$ Estimates for employed men range from 7.4 to 21.7 hours per week.

Supra note 4 at 57.

(1992), 102 Sask R. 250 (Q.B.) [hereinafter Mayes].

Walker, supra note 29.

In early research it was generally assumed that women were solely responsible for household work and child rearing and thus unpaid household work of men was rarely, if ever, studied.

J. Vanek, "Time Spent in Housework" (1974) 231:5 Scientific American 116 at 116.

Primary child care included physical care, teaching, helping and disciplining children, reading, talking or playing with children and travel related to child care which were reported as "primary" activities. It did not include child care activities which were reported as "secondary" to some other activity. Estimates vary because of differences in the sample, definitions of household work and data collection methods used. 


\begin{tabular}{|c|c|c|c|c|c|}
\hline \multicolumn{6}{|c|}{$\begin{array}{l}\text { TABLE 1: RESULTS OF CANADIAN TIME USE SURVEYS } \\
1965 \cdot 1986 \\
\end{array}$} \\
\hline \multirow[t]{2}{*}{$\begin{array}{l}\text { Author(s)/Publication } \\
\text { Date }\end{array}$} & \multirow[t]{2}{*}{$\begin{array}{l}\text { Survey Title } \\
\text { Description }\end{array}$} & \multirow[t]{2}{*}{$\begin{array}{l}\text { Survey } \\
\text { Date }\end{array}$} & \multicolumn{3}{|c|}{$\begin{array}{l}\text { Mean Hours/Week of Household Work } \\
\text { and Primary Child Care }\end{array}$} \\
\hline & & & $\begin{array}{l}\text { Employed } \\
\text { Women }\end{array}$ & $\begin{array}{l}\text { Homemaker } \\
\text { Women }\end{array}$ & Men \\
\hline $\begin{array}{l}\text { Meissner, Humphreys, } \\
\text { Meis \& Scheu } \\
(1975)^{41}\end{array}$ & $\begin{array}{l}\text { Study of Social, } \\
\text { Spacial \& Temporal } \\
\text { Ecology of Urban } \\
\text { Dwellers (Vancouver) }\end{array}$ & 1971 & 28.2 & 42.9 & 8.0 \\
\hline $\begin{array}{l}\text { Elliott \& Harvey \& } \\
\text { Procos }(1976)^{42} \\
\end{array}$ & $\begin{array}{l}\text { Halifax Time Budget } \\
\text { Study }\end{array}$ & 1971-72 & 26.3 & 47.5 & 11.3 \\
\hline $\begin{array}{l}\text { Harvey \& Elliott } \\
(1983)^{43}\end{array}$ & $\begin{array}{l}\text { Halifax Time Budget } \\
\text { Study }\end{array}$ & 1981 & 27.1 & 35.2 & 15.1 \\
\hline $\begin{array}{l}\text { Harvey, Elliott \& } \\
\text { Macdonald (1983) }\end{array}$ & $\begin{array}{l}\text { Canadian Time Use } \\
\text { Pilot Study }\end{array}$ & 1981 & $\begin{array}{l}18.9 \text { (full time) } \\
29.4 \text { (part time) }\end{array}$ & 42.0 & 13.3 \\
\hline $\begin{array}{l}\text { Fast \& Munro } \\
(1989)^{45}\end{array}$ & Keating \& Doherty & 1984 & N/A & 66.6 & 7.4 \\
\hline $\begin{array}{l}\text { Harvey, Marshall \& } \\
\text { Frederick (1991) }\end{array}$ & General Social Survey & 1986 & 29.4 & 51.8 & 21.7 \\
\hline
\end{tabular}

Research also has produced consistent evidence regarding predictors of household work time. Hours of paid employment and the presence and ages of children generally have been found to be the most influential variables in determining household work time of

M. Meissner et al., "No Exit for Wives: Sexual Division of Labour and the Cumulation of Household Demands" (1975) 12 (4) Part 1 Canada Rev. Soc. \& Anth. 424 at 434. and Leisure 145 at 156.

Canada Employment and Immigration Commission, Time and Time Again: Explorations in Time Use (Vol. 4) by A.S. Harvey \& D.H. Elliott (Ottawa, 1983) at 47.

44 Canada Employment and Immigration Commission, A Decade Later: Stability and Change in the Pattern of Time Use in the Halifax Panel (Vol. 8) by D.H. Elliot, A.S. Harvey \& W.S. MacDonald (1984) at 54-61. J.E. Fast \& B. Munro, "Value of Household and Farm Work: Evidence from Alberta Farm Family Data" (1991) 39 Can. J. Agri. Eco. 137 at 145.

Employment and Immigration Canada, Natcoon "How Canadians Use Their Time: Implications for Career Counselling" by A.S. Harvey (1983) 25 at 33 . 
women. ${ }^{47}$ Men's participation in household work varies by the same factors but to a much lesser extent. ${ }^{48}$

Returning to the above examples, Mrs. Logozar, described as a "very picky" housekeeper, claimed to do about forty-four hours of household work per week prior to her injury. This included about four hours per week spent tending an extensive vegetable garden and a flock of chickens which provided her family with eggs and meat. According to the most recent Canadian time use data available, Alberta women with employment and family characteristics similar to the plaintiff's spend between twenty-five and ninety-six hours per week doing household work. Consequently the plaintiff's reported weekly hours of household work are not excessive as compared with a representative sample of Alberta women. Nor is the assumption of the judge in Mayes ${ }^{49}$ that participation in household work declines with age supported by the data. On the contrary, data show that time spent doing household work may increase with age. ${ }^{50}$ While this is partly a result of decreased productivity due to physical limitations imposed by aging, it also is partly a result of having more uncommitted time available to devote to household work and other unpaid activities.

In other cases judges have stated that the injured homemaker is not entitled to compensation because her family should "pick up the slack" such that no real loss should be incurred. For example, in De Marco v. Toronto Transit Commission the judge accepted evidence that the plaintiff's daughter had provided a total of 980 hours of replacement household services and commented that this estimate may even have been conservative. Yet he allowed damages for only 400 hours of replacement services on the ground that the plaintiff's husband and sons "could have and should have assisted when they were home at night and on weekends. ${ }^{\text {"II } 1}$ Similarly, in Vykysaly v. Jablowski, the judge stated that it may be sexist to suggest that the wife will always do the housework. ${ }^{52}$ Where the husband and wife are both employed and contribute approximately equally to family income and household work, no award should be made. Such arguments fail on three counts. First, even if spouses work equal numbers of hours for pay, it cannot be assumed that they will equally share household work and child care responsibilities. On the contrary, as Table 1 shows, women do more hours of household work than men regardless of employment status. Whether comparable employment status means spouses should

See W.K. Bryant, C.D. Zick \& H. Kim, "Household Work: What's it Worth and Why?" Information Bulletin 322 IB228, Cornell Cooperative Extension, Ithaca, N.Y. 1992 at 3. See also M. AbdelGhany \& S.Y. Nickols, "Husband/Wife Differentials in Household Work time: The Case of DualEarner Families" (1983) 12:2 Home Economics Research J. 159. See also A.A. Brayfield, "Employment Resources and Housework in Canada" (1992) 54 J. Marr. and Fam. 19. See also F.T. Hall \& M.P. Schroeder, "Effects of Family and Housing Characteristics on Time Spent on Household Tasks" (1970) 62:1 J. Home Economics 23. See also Harvey, Marshall \& Frederick, supra note 29. See also Robinson, supra note 29. See also Walker, supra note 29 at 133. See also Wilson, supra note 5 .

Ibid.

Supra note 35.

See Harvey, Marshall \& Frederick, supra notc 29. See also Robinson, supra note 29.

(1978), 19 O.R. (2d) 691 at 694 (Co. Ct.).

(1992), 8 O.R. (3d) 181 (Gen. Div.). 
share household work equally thus becomes a moot point. Second, whether spouses share household work equally or not, some losses will be suffered if one or the other is prevented from doing what they would normally do. Either other family members will have to "pick up the slack" and substitute household work time for some other activity, which also has value, or the work will remain undone. The point is that the injured party simply is unable to make the same contribution s/he could before and should be compensated for the loss of that contribution in the same way that $s /$ he would be compensated for the loss of ability to contribute financial resources (earnings) to the family. Third, the expectation that family members should "pick up the slack" in household work further demonstrates a devaluation of household work as work. The courts do not have the same expectation that family members should "pick up the slack" in earnings if a breadwinner is injured. Why then should they be expected to replace equally productive but unpaid work?

In still other cases the plaintiff has failed, in the eyes of the court, to prove the extent to which the disability has affected his/her ability to perform the usual household work. For example, in Mayes ${ }^{53}$ the judge interpreted medical evidence regarding the proportion of body impairment as directly representing the proportionate reduction of the plaintiff's housekeeping capacity. However, given the physical demands of at least some household tasks, even a small overall body impairment can severely constrain the individual's ability to carry out the tasks.

\section{Valuing The Loss}

Even if agreement can be reached on the hours of household work for which the plaintiff should be compensated, a method for valuing that time still is required. The most common techniques for valuing non-market work include the opportunity cost method, the market alternative cost (generalist) method and the market alternative cost (specialist) method. In the opportunity cost method, based in household production theory, ${ }^{54}$ the value of unpaid work is measured as the earnings foregone as a result of deciding to work in the home instead of in the labour market. Thus the value of time is measured as the wage one can command in the labour market and the value of household work is calculated by multiplying the time spent doing household work by the individual's hourly labour market wage rate. ${ }^{55}$

In both market alternative cost methods, it is assumed that work done outside of the labour market has close market substitutes. Thus the value of household work is taken to equal the value of its market substitutes. In the case of the generalist version of the market alternative cost method, the value of household work is assumed to equal what it would cost to hire a general domestic worker to do the same work. The value of the individual's household work is calculated by multiplying the hours spent by the individual doing household work by the hourly wage of a general domestic worker.

53 Supra note 35 .

s4 G.S. Becker, "A Theory of the Allocation of Time" (1965) 75 The Economic J. 493.

ss For individuals not employed in the labour market, potential market wages are predicted using a statistical technique to correct for selectivity bias. 
The specialist version of the market alternative cost method differs from the generalist version in only one way. Instead of using the single wage rate of a general domestic worker to represent the value of all time spent in non-market work, wage rates corresponding to each component of the individual's non-market work are used. For example, the wage rate of a child care worker is multiplied by the hours spent by the individual caring for children, the wage rate of a short order cook is multiplied by the hours spent preparing meals, and so on. These products are then summed to obtain the total value of all non-market work in which the individual engages.

Given the availability of alternatives, each of which has its strengths and weaknesses, choice of the "right" technique has been the subject of heated debate in the academic literature. Yale suggests that the choice of appropriate method for the purposes of personal injury claims should be made less on the basis of computational complexity and more on the need for equitable treatment of claimants. ${ }^{56}$ Zick and Bryant conclude that the choice of technique depends on the question being addressed. ${ }^{57}$

On the ground of computational complexity, the primary advantages of the market alternative cost methods are their relative simplicity and limited data requirements. Kinsey $^{58}$ also describes their "approximation to reality" as an advantage since the experience of hiring someone to perform household tasks is not uncommon. In the opportunity cost method, computation of the value of household work time is carried out in the same way as for market alternative cost methods - hours spent doing household work is multiplied by the price of an hour of time. However, determining individuals' labour market wage rates which are used as the "price" of time is more complicated, requires more data and relies upon population averages to a greater extent. ${ }^{59}$

On the second ground of distributional equity, the need for equitable treatment of all claimants also is achieved by market replacement cost methods. Use of the same substitute worker wage rates for each individual would result in fairly standard awards which vary only by those individual and family characteristics which affect the amount of time devoted to household work. The opportunity cost method, on the other hand, is criticized because it results in significantly different estimated values for the same amount of work performed by different people. ${ }^{60}$ This occurs because workers with different characteristics will command different wage rates in the labour market. However, it should be noted that variations in labour market wage rates arise, at least in part, from variations

J. Yale, "The Valuation of Houschold Services in Wrongful Death Actions" (1984) 34 U.T.L.J. 283 at 304.

C.D. Zick \& W.K. Bryant, "Alternative Strategies for Pricing Home Work Time" (1983) 12:2 Home Economics Research J. 133 at 134-35.

J. Kinsey, "The Value of Time in Household Production Models" in R.E. Deacon \& W.E. Huffman, eds., Human Resources Research 1887-1987 (Ames, Iowa: College of Home Economics, Iowa State University, 1986) 187 at 189.

Labour market wage rates for specific individuals usually are predicted from the results of statistical analyses of labour market participation and earnings data from nationally representative surveys. "Personalized" predictions can be obtained by disaggregating results by individual characteristics such as gender, age and employment status. 
in productivity among workers. Similar variability in productivity exists among household workers. In addition, similar personal characteristics (such as education and experience) are associated with variable productivity in both the labour market and the household. Consequently, variations in the value of time among individuals are to be expected and, to the extent that they result from individual differences in productivity, should be reflected in estimates of the value of household work time. In fact, failure to do so may imply the undesirable assumption that "all housewives are identical as to ability in home management, mental and physical capacity. ${ }^{161}$ Further, as Yale points out, opportunity cost estimates achieve a different type of distributional equity in personal injury awards in that individuals with similar skills and occupational opportunities would receive the same level of compensation whether their time was allocated primarily to the labour market or to household production. ${ }^{62}$

With respect to the final choice criterion, the question raised in cases of personal injury is precisely one of the cost of replacing lost services. Réaume described the basic objective of tort law damages as restoring the plaintiff, to the extent that money is able to do so, to the position s/he would have been in if the injury had not occurred. ${ }^{63}$ An injury to someone with household responsibilities results in loss of the ability to perform work for which one could purchase market substitutes which would approximately restore them to their pre-injury situation. Cooper-Stephenson \& Saunders state that replacement cost "...provides the vehicle for true compensation in restitutionary form, since the damages awarded may then be used to replace as nearly as possible the services lost. ${ }^{164}$ Further, the generalist and specialist replacement cost methods correspond to the "substitute homemaker" and "catalogue of services" approaches respectively, as described by Vancise J.A. in the case of Fobel. ${ }^{65}$ Consequently, a combination of the generalist and specialist replacement costs should reasonably achieve the "combination of the substitute homemaker/catalogue services approach"166 advocated by the Saskatchewan Court of Appeal.

In sum, replacement cost methods are recommended for purposes of valuing lost housekeeping capacity in personal injury claims. They are the least computationally complex, they achieve at least one type of distributional equity and they come closest to achieving the goal of returning the plaintiff to his/her pre-injury position. Replacement cost methods are not without problems, however. For example, neither replacement cost method accounts for the fact that market alternatives may not be perfect substitutes for home produced commodities. Quality differentials associated with the unique way in which family members perform their role(s) may exist between services provided by family members and those provided by hired professionals. ${ }^{67}$ The specialist method fails

C.S. Pyun, "The Monetary Value of a Housewife: An Economic Analysis for Use in Litigation" (1969) 28:3 American J. of Economics \& Soc. 271 at 274.

Supra note 56 at 305.

Supra note 21 at 101 .

Supra note 15 at 218 .

Supra note 11 .

Ibid. at 398.

Yale, supra note 56 at 295. 
to account for the greater productivity of hired specialist as compared with household workers in specific tasks. The generalist method underestimates the value of managerial skills: even if the household is able to hire acceptable substitute services, someone (a family member) must co-ordinate and supervise the employee's work. Further, the generalist method allows for some forms of joint production $^{68}$ while the specialist method does not. ${ }^{69}$

In practice, Canadian courts have most commonly applied some variation of the replacement cost approach. However, there still seems to be a tendency to underestimate the market cost of the replacement services. For example in Logozar, Wilson J., after reviewing expert evidence regarding wage rates paid for substitute household labour, stated "I think, however, that the hours claimed are too high, and so is the rate. ${ }^{170}$ No reason as to why he believed the rate to be too high was given. The rate he applied was $\$ 7.00$ per hour; that claimed by the plaintiff was $\$ 8.48$ which was the average wage, in 1992 dollars, paid to light duty cleaners in the neighbouring province of Saskatchewan as reported in the Saskatchewan Labour and Employment document, Wages and Working Conditions by Occupation. Even in the case of Fobel, in spite of "uncontradicted evidence that as at September, 1984, the average wage payable for domestic services was $\$ 7.54$ an hour, ${ }^{, 71}$ the wage rate applied for the purposes of calculating the value of lost housekeeping services was reduced to $\$ 5.50$ because the court was prepared to assume that the cost of hiring by the week or month would be less. However, it should be noted that hours of replacement labour required was set at 15 hours per week which is unlikely to enable the plaintiff to hire on a weekly or monthly basis.

Even if prevailing wage rates were proven and accepted by the court, Cassels notes that "...wage rates in the labour market continue to reflect gender bias" such that reliance by the courts on average earnings to value lost household production (or earnings) "reproduc[es] any gender bias in the market. ${ }^{172}$ That is, occupations corresponding to household tasks for which wage rates are used as representative of the value of household work time tend to be ones in which women are over-represented and which tend to be undercompensated. Application of these downward-biased wage rates to the task of

Joint production refers to the fact that individuals may engage in more than one activity at a time. One may be keeping an eye on children while doing housework. Joint production also may refer to the fact that utility (or disutility) may be derived from time spent engaging in household work both directly and indirectly - indirectly from consumption of the commodities that are produced and directly from enjoyment (or dislike) of the activity itself. While the generalist method allows for the first type of joint production, the extent to which an individual derives pleasure (or displeasure) from time spent doing unpaid household work may affect time allocation decisions and so bias estimates of the value of the work.

See Yale, supra note 56 at 299. See also Zick and Bryant, supra note 57 at 134. See also 0. Hawrylyshyn, "Towards a Definition of Non-Market Activities" (1977) 23:1 The Review of Income and Wealth 79.

*) Supra note 4 at 57 [emphasis added].

1 Supra note 11 at 401.

$12 \quad$ Supra note 19 at 471-72.

Since gender-based wage discrimination contravenes current human rights legislation, it could even be said that courts are engaging in an illegal act by reproducing labour market gender bias in their decisions. 
computing the replacement value of household work would result in further undercompensation.

\section{CONCLUSION}

In conclusion, some advances have been made with respect to the way the Canadian legal system deals with unpaid but productive work. Still, there is substantial evidence that gender bias continues to depress awards in cases of personal injury which affects the plaintiffs' ability to do unpaid household work. Reconceptualization of the plaintiff's loss as that of the capacity to do economically valuable work would represent a significant step forward. Such a reconceptualization would help to integrate like losses and so result in more equitable treatment of plaintiffs. It also would facilitate reliance on economic evidence regarding time allocation and adoption of economic methods for valuation of unpaid work for the purposes of determining appropriate levels of compensation. 


\section{JUSTICE FOR VICTIMS? - THE SENTENCING OF \\ PUBLIC TRUST FIGURES CONVICTED OF CHILD \\ SEXUAL ABUSE: A FOCUS ON RELIGIOUS LEADERS}

\section{JAMIE MARTIN}

\begin{abstract}
Child sexual abuse has recently been recognized as being much more pervasive than was once thought. The author addresses the recent increase in awareness of child sexual abuse and in particular, he comments on sentencing in child sexual abuse cases. From a historical account of the crime, the author proceeds to narrow his focus to that of child sexual abuse committed by those in positions of trust, particularly religious figures. The author discusses the sentencing patterns of such offenders with an analysis of recent case law. He concludes by speculating on future sentencing trends with respect to child sexual abuse offenders generally.
\end{abstract}

On reconnaît depuis peu que l'exploitation sexuelle des enfants est beaucoup plus répandue qu'on ne le pensait. L'auteur constate une sensibilisation récente à cet égard et se penche plus particulièrement sur les décisions rendues dans les cas de violence sexuelle perpétrée contre les enfants. L'auteur commence par effectuer l'historique de ce crime et concentre ensuite son attention sur les agressions sexuelles commises par les personnes qui occupent des postes de confiance, dans le domaine religieux surtout. L'auteur discute du type de sanctions imposées aux coupables et procède à l'analyse des cas récents de jurisprudence. Il conclut en formulant quelques suppositions sur les tendances futures des sentences prononcées contre les coupables d'agressions sexuelles contre les enfants.

\section{TABLE OF CONTENTS}

I. INTRODUCTION $\ldots \ldots \ldots \ldots \ldots \ldots \ldots \ldots \ldots \ldots \ldots$

II. RESEARCH METHODOLOGY - FRAMEWORK

OF ARTICLE . . . . . . . . . . . . . . . . . . . 19

III. HISTORY OF CHILD SEXUAL ABUSE $\ldots \ldots \ldots \ldots \ldots \ldots \ldots 20$

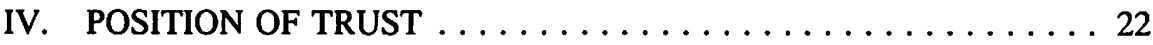

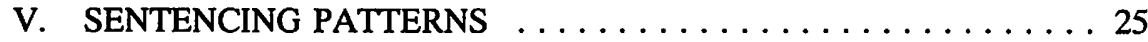

VI. PRINCIPLES AND FACTORS IN SENTENCING $\ldots \ldots \ldots \ldots \ldots 28$

A. PRELIMINARY OBSERVATIONS -

LIMITED USE OF VENGEANCE . . . . . . . . . . . . . 29

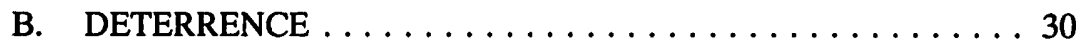

C. REHABILITATION OF THE OFFENDER $\ldots \ldots \ldots \ldots \ldots 31$

D. IMPACT ON THE VICTIM $\ldots \ldots \ldots \ldots \ldots \ldots \ldots \ldots \ldots$

VII. SUMMARY AND CONCLUSIONS $\ldots \ldots \ldots \ldots \ldots \ldots \ldots \ldots 33$

A. FUTURE SENTENCING PATTERNS FOR RELIGIOUS FIGURES - CHILD

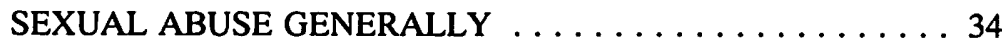

\section{INTRODUCTION}

This article examines principles of sentencing employed by the courts in cases involving religious figures in positions of public trust who are convicted of child sexual

Third year student, Faculty of Law, University of Alberta. Recipient of the 1993 William J. Browne

Scholarship Essay competition sponsored by the Law Society of Newfoundland. 